\title{
Effect of Different Inoculum Levels of Ascochyta lentis on Growth and Yield Attributes of Lentil Plant
}

\author{
Shahbaz Talib Sahi ${ }^{1}$, Muhammad Atiq ${ }^{1, *}$, Talfoor-ul-Hassan ${ }^{1}$, Muhammad Shafiq ${ }^{2}$, Yasir Ali $^{1}$, \\ Shafqat Ali ${ }^{1}$, Tanvir Ahmad ${ }^{1}$, Ahmad Subhani ${ }^{1}$, Aiman Zulfiqar ${ }^{1}$, Komal Mazhar $^{3}$ \\ ${ }^{1}$ Department of Plant Pathology, University of Agriculture Faisalabad, Pakistan \\ ${ }^{2}$ Directorate General of Agriculture (Water Management), Punjab Lahore, Pakistan \\ ${ }^{3}$ Department of Forestry and Range Management, University of Agriculture, Faisalabad, Pakistan
}

Copyright $\odot 2018$ by authors, all rights reserved. Authors agree that this article remains permanently open access under the terms of the Creative Commons Attribution License 4.0 International License

\begin{abstract}
Effect of different inoculums levels $\left(10^{3}\right.$, $5 \times 10^{3}, 10^{4}, 5 \times 10^{4}$ spores $\left./ \mathrm{ml}\right)$ of $A$. lentis was studied on growth and yield parameters of four lines of lentil. Results showed that among these lines one (ILL-358) showed microsperma resistant, one (ILL-4605) macrosperma resistant, one (ILL-5580) microsperma susceptible and the remaining one (ILL-6002) macrosperma susceptible response over control. Plant height was the minimum in case of all the four lentil lines are at 5 spores $/ \mathrm{ml}$. Similarly no. of leaflets, no. of pods/ plant, no. of grains/pod and 100 grain weight were reduced with increased level of spores concentration from $10^{3}$ spore $/ \mathrm{ml}$ to $5 \times 10^{4}$ spore $/ \mathrm{ml}$. Size and frequency of lesions/pods showed positive correlation with increasing spore concentrations.
\end{abstract}

Keywords Ascochyta Blight, Inoculum Levels, Lentil, Spore Concentrations

\section{Introduction}

Lentil is the most important pulse crop after gram. It is quite popular among the people due to its delicious taste and high protein contents $(28.6 \%)$. So it is a potential substitute of meat especially for poor community. In Pakistan during 1997-98 the area under lentil was 64.8 thousand hectares with average yield $571 \mathrm{~kg} / \mathrm{ha}$. This yield is extremely low as compared to other countries of the world. The low yield in Pakistan may be attributed to several factors, one of the most important factors being the damage by diseases. The most common diseases of lentil in Pakistan are blight and rust. Blight is caused by Ascochyta fabae f.sp. lentis. Ascochyta blight is the most important foliar disease of lentil. The disease is able to cause serious reduction in yield under congenital weather conditions. The disease may lead to growth and yield reduction to the extent of $24-59 \%$ and more than $25 \%$ respectively even though the environment may be unfavorable for its spread $[4,5 \& 6]$.

A. lentis is specific to cultivated and wild species of lentil [7]. It is morphologically indistinct from A. fabae but the latter is unable to infect lentil species [8]. Movement of lentil germplasm has spread the pathogen all over the world [8] where it is primarily introduced to new sites through infected seed [10]. Wind dispersal of ascospores from diseased lentil debris into neighboring fields is considered the primary source of inoculum in Australia and the entire world [9] while rain dispersal of asexual pycnidiospores in prolonged damp conditions leads to rapid outbreak of this disease. Sexual ascospores are produced on lentil stubble from the previous crop when both fungal mating types, MAT1-1 and MAT1-2, are present, leading to increased genetic diversity and adaptive potential [11]. The ascospores are produced during the growing season in late autumn and winter and are wind dispersed to a distance of $50 \mathrm{~m}$ from infected stubble [13].

Keeping in view all above mention facts present study was conducted to observe the effect of different inoculum levels of A. lentis on the development of Ascochyta blight on lentil plants.

\section{Materials and Methods}

\section{Isolation of Ascochyta lentis}

Diseased pods of lentil showing characteristic symptoms of blight disease were collected from lentil fields of Department of Plant Pathology University of Agriculture Faisalabad during September 25, 2015 and Kept in refrigerator at $5-8{ }^{0} \mathrm{C}$ for isolation. Then these pods were flamed in such a way that for charring of outer layer of the pod with the help of forceps. Then, pressed the pods with flame sterilized forceps to remove the seeds aseptically. These naturally infected seeds were plated on autoclaved 
6\% Lentil Seed Meal Agar (LSMA) medium in $90 \mathrm{~mm}$ petridishes. These petridishes were incubated at $20 \pm 2$ with 12 hours light alternating with 12 hours of darkness for two weeks. Then pure culture of $A$. lentil was obtained by using streak method [14]. The pure culture was grown on $6 \%$ LSMA in test tube and stored in refrigerator at $5-6^{\circ} \mathrm{C}$.

\section{Preparation of Mass Culture and Different Inoculum Levels of $A$. lentis}

After this mass culture of $A$. lentis was prepared. For this purpose gram seeds were soaked for 18 hours and then boiled for 2-3 minutes in pressure cooker. These boiled grains were air dried in shade for 3-4 hours and then filled in polythene bags $(200 \mathrm{~g} / \mathrm{bag})$ and autoclaved at $20 \mathrm{lbs}$ PSI for thirty minutes twice interval of 24 hours $50 \mathrm{mg}$ of streptomycin was also added to each bag in order to inhibit bacterial contamination. Upon cooling they were inoculated with 5-mm disc of 14 days old culture. These bags were incubated at $22{ }^{\circ} \mathrm{C}$ under continuous light. It took 5-7 days for abundant development of pycnidia of the fungus on inoculated grains. These grains were mashed in sterile water and filtered through double layer of muslin cloth for preparing spore suspension. After spore counting through haemocytometer and observing germination percentage under microspore four different inoculum concentrations $\left(10^{3}, 5 \times 10^{3}, 10^{4}\right.$, and $5 \times 10^{4}$ spores $\left./ \mathrm{ml}\right)$ were prepared for spraying the lentil plants by using following formula.

$$
\begin{aligned}
& \mathrm{N}_{1} \mathrm{~V}_{1}=\mathrm{N}_{2} \mathrm{~V}_{2} \\
& \mathrm{~N}_{1}=\text { number of spores in stock spore suspension } \\
& \mathrm{N}_{2}=\text { required number of spores } \\
& \mathrm{V}_{1}=\text { volume of stock spore suspension } \\
& \mathrm{V}_{2}=\text { Volume to be prepared with required number of } \\
& \text { spores }
\end{aligned}
$$

Effect of Different Inoculum Levels on the Development of Ascochyta Blight and Growth of Lentil Plants

For evaluation of different inoculum concentrations of $A$. lentis, ten pots (9" 6 ") of each line with eight seeds were sown (ILL 358, ILL 4605 were resistant and ILL 2580, ILL 6002 were susceptible). Pots were kept in green house and then seedlings were allowed luxuriantly in natural environment. Fifty days after emergence when the lentil plants were at their tender stage of growth, two pots of each four lines were sprayed with spore suspensions containing $10^{3}, 5 \times 10^{3}, 10^{4}, 5 \times 10^{4}$ spores $/ \mathrm{ml}$, the remaining two pots of each line served as control/check. Pots were inoculated three times with two days interval. Two provide the lentil plants with sufficient humidity for disease development; they were covered for first eight days with polythene sheets after inoculation. Pots were also sprayed frequently with simple water to provide proper humidity. Then effect of different inoculum concentrations were observed on height of lentil plant, no. of leaflets, no. of pods /plant, weight of hundred seeds were observed and compared with control.

\section{Statistical Analysis}

Statistical analysis of data was carried out using computer program $\mathrm{M}$ stat $\mathrm{C}$ and $\mathrm{HG} 4$.

\section{Results}

The ANOVA showed that the effect of different spore concentration on plant height, leaflets/plant, pods/plant and grains/pod was highly significant (Table 1). Similarly varieties with both groups exhibited statistically highly significant effect by different spore concentration.

In the resistant group the means of final plant heights inoculated with $1000,5000,10000$ and 50000 spores $/ \mathrm{ml}$ were $32.13,31.11,30.26$ and 28.44 which were statistically different from one another significantly. Thus as the spore concentration increased plant height decreased. The uninoculated plants have $34 \mathrm{~cm}$ plant height which is significantly higher than inoculated plant heights. In the susceptible group plant height was significantly variable with varying spore concentrations. In this group average plant height at $10^{3}, 5 \times 10^{3}, 10^{4}, 5 \times 10^{4}$ spores/ $\mathrm{ml}$ were 29.56 , 28.46, 23.25 and 19.26 respectively (Table 2).

Upon inoculation lentil plants with A. lentis, the no. of leaflets decreased at highly significant levels with increasing the spore concentration in both the groups, but the interaction of inoculum levels with varieties in each of two groups was non-significant. In the resistant groups the no. of leaflets of the plants inoculated with $10^{3}, 5 \times 10^{3}$ and $10^{4}$ spores $/ \mathrm{ml}$ were $120.3,119.4$ and 117.8 which was statistically at par but no. of leaflets of the plants sprayed with $5 \times 10^{4}$ spores $/ \mathrm{ml}$ was significantly lower (113.1) than the former three. The un-inoculated plants leaflets (124.5) which was significantly higher than the plants inoculated at all the four spore concentrations. On the other hand the response of varieties in the susceptible group was quite variable as compared to those of the resistant group. In this group there was significant decrease in the no. of leaflets with increasing concentration of spore suspension. Consequently the mean no. of leaflets was 119.3, 111.0, 102.9 and 93.25 in plants inoculated with spore suspensions having $1000,5000,10,000,50,000$ spore/ml respectively (Table 2). 
Table 1. ANOVA for plant height, no. of leaflets, no. of pods/plant, no. of grains/pod inoculated with four different concentrations of $A$. lentis

\begin{tabular}{|c|c|c|c|c|c|}
\hline S.O.V & D.F & $\begin{array}{c}\text { MS of } \\
\text { Plant height }\end{array}$ & $\begin{array}{c}\text { MS of } \\
\text { Leaflet/plant }\end{array}$ & $\begin{array}{c}\text { MS of } \\
\text { Pods/plant }\end{array}$ & MS of grains/pod \\
\hline Replication & 3 & $0.60 \mathrm{NS}$ & $19.789 \mathrm{NS}$ & $1.446 \mathrm{NS}$ & 0.004 \\
\hline Groups & 1 & $434.06^{* *}$ & $1593.11^{* *}$ & $94.613^{* *}$ & $0.086^{* *}$ \\
\hline Error (a) & 3 & 0.55 & 1.846 & 0.646 & 0.001 \\
\hline Error (b) & 1 & $170.16^{* *}$ & $67.600 \mathrm{NS}$ & $2.500 \mathrm{NS}$ & $0.301^{* *}$ \\
\hline Varieties with in resistant group (A) & 3 & 0.53 & 5.800 & 0.633 & 0.000 \\
\hline Varieties with in susceptible group (B) & 1 & $2667.96^{* *}$ & $27.225 \mathrm{NS}$ & $9.025 \mathrm{NS}$ & $0.692^{* *}$ \\
\hline Error (c) & 3 & 1.085 & 6.292 & 0.892 & 0.001 \\
\hline Inoculum levels with in resistant group (C) & 4 & $34.426^{* *}$ & $136.063^{* *}$ & $12.287^{* *}$ & $0.070^{* *}$ \\
\hline AxC & 4 & $4.544^{* *}$ & $11.913 \mathrm{NS}$ & 1.063 & $0.020^{* *}$ \\
\hline Error (d) & 24 & 0.461 & 8.954 & 0.992 & 0.001 \\
\hline Inoculum levels with in susceptible group (D) & 4 & $217.02^{* *}$ & $1227.725^{* *}$ & $91.087^{* *}$ & $0.185^{* *}$ \\
\hline BxD & 4 & $17.719^{* *}$ & $19.975 \mathrm{NS}$ & $0.087 \mathrm{NS}$ & $0.028^{* *}$ \\
\hline Error (e) & 24 & 0.891 & 7.883 & 0.671 & 0.001 \\
\hline Total & 79 & & & & \\
\hline
\end{tabular}

NS $=$ Non significant

** = Highly significant at $P \leq 0.01$

Table 2. Effect of different inoculum concentrations of A. lentis on plant height, no. of leaflets, pods and grains per plant of resistant and susceptible groups of lentil plants

\begin{tabular}{|c|c|c|c|}
\hline \multicolumn{4}{|c|}{ Response of different parameters of resistant and susceptible groups of lentil plants against different inoculum concentrations of $A$. lentis } \\
\hline Group & \multicolumn{3}{|c|}{ Height of lentil plant } \\
\hline A & Inoculum level & Resistant group & Susceptible group \\
\hline 1 & 1000 & $32.13 \mathrm{~b}$ & $29.56 \mathrm{~b}$ \\
\hline 2 & 5000 & $31.11 \mathrm{c}$ & $28.46 \mathrm{c}$ \\
\hline 3 & 10000 & $30.26 \mathrm{~d}$ & $23.25 \mathrm{~d}$ \\
\hline \multirow[t]{2}{*}{4} & 50000 & $28.44 \mathrm{e}$ & $19.26 \mathrm{e}$ \\
\hline & Control & $34.00 \mathrm{a}$ & $32.19 \mathrm{a}$ \\
\hline B & \multicolumn{3}{|c|}{ No. of leaflets } \\
\hline 1 & 1000 & $120.3 b$ & $119.3 b$ \\
\hline 2 & 5000 & $119.4 b$ & $111.0 \mathrm{c}$ \\
\hline 3 & 10000 & $117.8 \mathrm{~b}$ & $102.9 \mathrm{~d}$ \\
\hline \multirow[t]{2}{*}{4} & 50000 & $113.1 \mathrm{c}$ & $93.25 \mathrm{e}$ \\
\hline & Control & $124.5 \mathrm{a}$ & $124.0 \mathrm{a}$ \\
\hline $\mathbf{C}$ & \multicolumn{3}{|c|}{ No. of pods per plant } \\
\hline 1 & 1000 & $11.13 b$ & $9.500 \mathrm{~b}$ \\
\hline 2 & 5000 & $11.13 b$ & $9.625 b$ \\
\hline 3 & 10000 & $10.00 \mathrm{c}$ & $6.375 \mathrm{c}$ \\
\hline \multirow[t]{2}{*}{4} & 50000 & $9.000 \mathrm{c}$ & $5.500 \mathrm{~d}$ \\
\hline & Control & $12.25 \mathrm{a}$ & $11.63 \mathrm{a}$ \\
\hline D & \multicolumn{3}{|c|}{ No. of grains per pod } \\
\hline 1 & 1000 & $1.425 \mathrm{~b}$ & $1.533 b$ \\
\hline 2 & 5000 & $1.404 \mathrm{~b}$ & $1.484 \mathrm{c}$ \\
\hline 3 & 10000 & $1.337 \mathrm{c}$ & $1.349 \mathrm{~d}$ \\
\hline \multirow[t]{2}{*}{4} & 50000 & $1.229 \mathrm{c}$ & $1.224 \mathrm{e}$ \\
\hline & Control & $1.469 \mathrm{a}$ & $11.63 \mathrm{a}$ \\
\hline
\end{tabular}

In these groups (Susceptible and resistant) the un-inoculated plants exhibited 124 leaflets that was significantly higher than the plants treated with the spore suspension at all the concentrations. When the data was subjected to regression analysis the intercept for ILL 358, 4605,2580 and 6002 was $122.34,120.23,116.80$ and 116.89 respectively and the slope was $0.000155,0.000190$, 0.000447 and 0.000578 respectively. Negative correlation was calculated in four varieties and $r$ values were -0.102 ,
$-0.156,-0.064$ and -0.281 respectively. Thus, $\mathrm{r}$ values were statistically significant $(\mathrm{P}<0.05)$ for the varieties ILL 358 and 6002 out of which 358 was resistant and 6002 was susceptible to $A$. lentis while $\mathrm{r}$ value were non-significant for the varieties ILL 4605 and 2580, out of which ILL 4605 was resistant while remaining 2580 was susceptible to $A$. lentis. (Figure 1).

When lentil plants were inoculated with different spore concentrations of A. lentis, no. of pods decreased at a 
highly significant level, but the interaction of inoculum levels with varieties in each of two groups was non-significant. In the resistant group the no. of pods/plant of lentil inoculated with $10^{3}$ and $5 \times 10^{3}$ spores $/ \mathrm{ml}$ was 11.13 and 11.13 that were statistically similar. When the spore concentration was increased up to $10^{4}$ and $5 \times 10^{4}$ spores $/ \mathrm{ml}$, no. of pods $/$ plant were 10 and 9 that were statistically at par with respect to each other but significantly lower than the former two spore levels (Table 2). On the other hand un-inoculated plants had no. of pods (12.25) that are significantly higher than the plants inoculated with all the four concentrations. In case of susceptible group the response of varieties was quite variable as compared with resistant group. In this group there were recorded significantly decreased no. of pods/plant as the spore concentrations were increased from
$10^{3}$ spore $/ \mathrm{ml}$ to $5 \times 10^{4}$ spore $/ \mathrm{ml}$. So the mean no. of pods/ were 9.5,9.62,6.37 and 5.50 in the plants inoculated with spore suspensions having 103, 5x103, 104 and $5 \times 10$ spores/ml respectively, while un-inoculated plants had 11.63 no. of pods/ plant that were significantly higher that the plants sprayed with all the four spore concentrations (Table 3). When the data was subjected to regression analysis the intercept for ILL 358, 4605, 2580 and 6002 was $11.47,11.01,10.24$ and 9.31 respectively and the slope was $0.0000595,0.0000424,0.0000942$ and 0.0000578 respectively. Negative correlation was calculated in four varieties and $r$ values were $-0.865,-0.791,0.779$ and -0.790 . Thus, $r$ values were statistically non-significant $(\mathrm{P}>0.05)$ for all the four varieties, thereby showing almost no relation between increasing spore concentration and no of pods/ plant. (Figure 2).

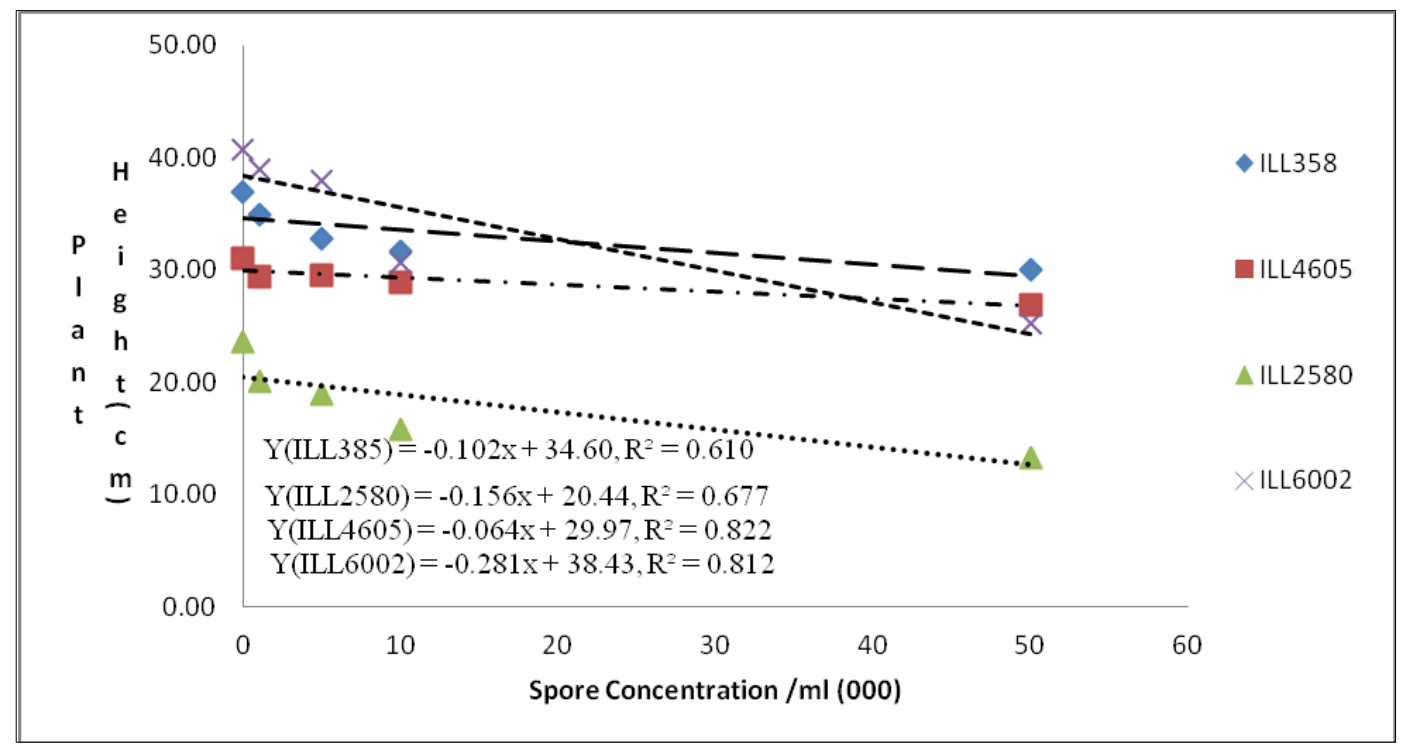

Figure 1. Relationship of resistant and susceptible lentil cultivars with different level of spore concentration of $A$. lentis

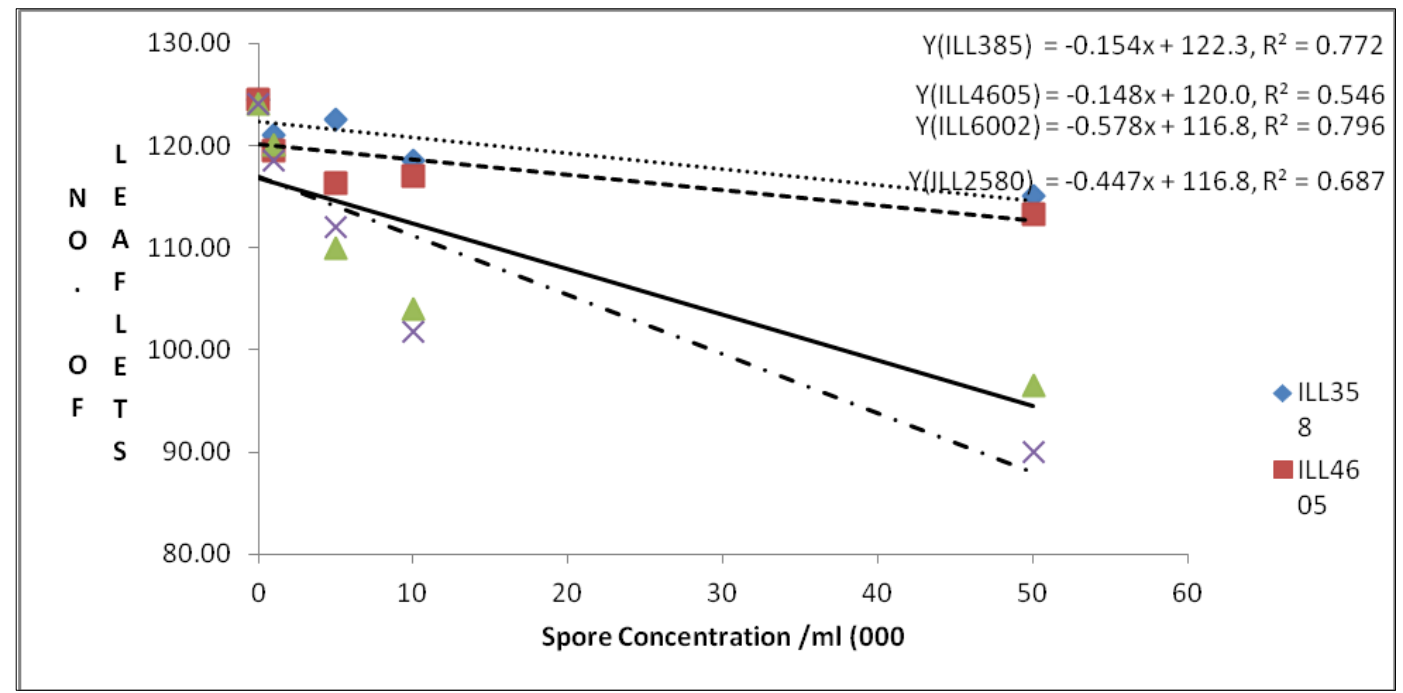

Figure 2. Relationship of plant growth with different level of spore concentration on Y(ILL358), Y(ILL4605), Y(ILL6002), Y(ILL6002) and Y(ILL2580) lentil varieties 
The Analysis of Variance of data regarding no. of grains/pod indicated that no. of grains/pod in both groups resistant and susceptible is highly significantly variable upon inoculation with different spore concentrations of Ascochyta lentis. As the inoculum level increased from lower to higher concentration, no. of grains/pod decreased in both groups at a highly significant level. Similarly interaction of inoculum levels with varieties in each group was also highly significant, i.e. different spore concentration had different effect or varieties within each group. In the resistant group no. of grains/pod of plants inoculated with $1000 \mathrm{spore} / \mathrm{ml}$ and $5000 \mathrm{spores} / \mathrm{ml}$ were 1.425 and 1.404 that are statistically similar. When spore concentration was increased to 10,000 and $50,000 \mathrm{spore} / \mathrm{ml}$, no. of grains/pod reduced to 1.337 and 1.229 which are significantly lower than the former. The uninoculated plants had 1.469 no. of grains/pod that are significantly higher than the plants inoculated with all the four concentrations of inoculum levels. In the susceptible group the no. of grains/pod of plants inoculated with spore concentrations of $1000,5000,10,000,50,000$ spores $/ \mathrm{ml}$ were $1.533,1.484,1.349,1.224$ respectively. It means that with every on step increase of spore concentration no. of grains/pod decrease significantly as compared with the former. The un-inoculated plants/control produced 1.604 no. of grains/pod that are significantly higher than the no. of grains produced by inoculated plants at all four spore concentrations of inoculum of $A$. lentis. (Table 3 )

Table 3. Effect of different inoculum concentrations of $A$. lentis on plant height no. of leaflets, pods and grains per plant of microsperma and macrosperma resistant and susceptible groups of lentil plants

\begin{tabular}{|c|c|c|c|c|c|}
\hline \multicolumn{6}{|c|}{ Response of different parameters of resistant and susceptible groups of lentil plants against different concentrations of $A$. lentis } \\
\hline \multirow{2}{*}{$\begin{array}{c}\text { Group } \\
\text { A }\end{array}$} & \multicolumn{5}{|c|}{ Height of lentil plant } \\
\hline & $\begin{array}{c}\text { Inoculum } \\
\text { level }\end{array}$ & $\begin{array}{c}\text { Microsperma } \\
\text { resistant } \\
\text { ( ILL 358) } \\
\end{array}$ & $\begin{array}{c}\text { Macrosperma } \\
\text { resistant } \\
\text { (ILL 4605) } \\
\end{array}$ & $\begin{array}{c}\text { Microsperma susceptible } \\
\text { ( ILL 5580) }\end{array}$ & $\begin{array}{c}\text { Macrosperma susceptible } \\
\text { (ILL6002) }\end{array}$ \\
\hline 1 & 1000 & $34.88 \mathrm{~b}$ & $29.38 \mathrm{ef}$ & $20.13 \mathrm{~g}$ & $39.00 \mathrm{f}$ \\
\hline 2 & 5000 & $32.75 \mathrm{c}$ & $29.48 \mathrm{ef}$ & $19.00 \mathrm{~h}$ & $37.92 \mathrm{c}$ \\
\hline 3 & 10000 & $31.63 \mathrm{~d}$ & $28.90 \mathrm{f}$ & $15.82 \mathrm{i}$ & $30.67 d$ \\
\hline \multirow[t]{2}{*}{4} & 50000 & $30.00 \mathrm{e}$ & $26.88 \mathrm{~g}$ & $13.30 \mathrm{j}$ & $25.23 \mathrm{e}$ \\
\hline & Control & $37.00 \mathrm{a}$ & $31.00 \mathrm{~d}$ & 23.63 & $40.75 \mathrm{a}$ \\
\hline B & \multicolumn{5}{|c|}{ No. of leaflets } \\
\hline 1 & 1000 & $121.0 \mathrm{abc}$ & $119.5 \mathrm{bcd}$ & $120.0 \mathrm{ab}$ & $118.5 \mathrm{~b}$ \\
\hline 2 & 5000 & $122.5 \mathrm{ab}$ & $116.3 \mathrm{de}$ & $110.0 \mathrm{c}$ & $112.0 \mathrm{c}$ \\
\hline 3 & 10000 & 118.5 bcde & $117.0 \mathrm{cde}$ & $104.0 \mathrm{~d}$ & $101.8 \mathrm{~d}$ \\
\hline \multirow[t]{2}{*}{4} & 50000 & $115.0 \mathrm{ef}$ & $113.3 \mathrm{f}$ & $96.50 \mathrm{e}$ & $90.00 \mathrm{f}$ \\
\hline & Control & $124.5 \mathrm{a}$ & $124.5 \mathrm{a}$ & 124.0 & $124.0 \mathrm{a}$ \\
\hline $\mathbf{C}$ & \multicolumn{5}{|c|}{ No. of pods per plant } \\
\hline 1 & 1000 & $12.00 \mathrm{ab}$ & $10.25 \mathrm{~cd}$ & $10.00 \mathrm{~cd}$ & $9.000 \mathrm{~d}$ \\
\hline 2 & 5000 & $11.25 \mathrm{abc}$ & $11.00 \mathrm{bc}$ & $10.25 \mathrm{bc}$ & $9.000 \mathrm{~d}$ \\
\hline 3 & 10000 & $10.00 \mathrm{~cd}$ & $10.00 \mathrm{~cd}$ & $6.750 \mathrm{e}$ & $6.000 \mathrm{ef}$ \\
\hline \multirow[t]{2}{*}{4} & 50000 & $9.000 \mathrm{~d}$ & $9.000 \mathrm{~d}$ & $6.000 \mathrm{ef}$ & $5.000 \mathrm{f}$ \\
\hline & Control & $12.50 \mathrm{a}$ & $12.00 \mathrm{ab}$ & $12.00 \mathrm{a}$ & $11.25 \mathrm{ab}$ \\
\hline D & \multicolumn{5}{|c|}{ No. of grains per pod } \\
\hline 1 & 1000 & $1.527 \mathrm{~b}$ & $1.322 \mathrm{de}$ & $1.707 \mathrm{~b}$ & $1.358 \mathrm{e}$ \\
\hline 2 & 5000 & $1.530 \mathrm{~b}$ & $1.277 \mathrm{ef}$ & $1.628 \mathrm{c}$ & $1.340 \mathrm{e}$ \\
\hline 3 & 10000 & $1.390 \mathrm{c}$ & $1.285 \mathrm{ef}$ & $1.435 \mathrm{~d}$ & $1.263 \mathrm{f}$ \\
\hline 4 & 50000 & $1.247 \mathrm{fg}$ & $1.210 \mathrm{~g}$ & $1.280 \mathrm{f}$ & $1.168 \mathrm{~b}$ \\
\hline & Control & $1.602 \mathrm{a}$ & $1.335 \mathrm{~d}$ & $1.800 \mathrm{a}$ & $1.408 \mathrm{~d}$ \\
\hline
\end{tabular}


Table 4. Effect of different inoculum concentrations of A. lentis on disease severity on microsperma and macrosperma resistant and susceptible groups of lentil plants

\begin{tabular}{|c|c|c|c|c|c|}
\hline $\begin{array}{c}\text { Group } \\
\text { A }\end{array}$ & $\begin{array}{l}\text { Inoculum } \\
\text { level }\end{array}$ & $\begin{array}{c}\text { Microsperma resistant } \\
\text { ( ILL 358) } \\
100 \text { Grain weight } \\
\end{array}$ & $\begin{array}{c}\text { \% Decrease over } \\
\text { control }\end{array}$ & $\begin{array}{c}\text { Macrosperma resistant } \\
\text { (ILL 4605) } \\
100 \text { Grain weight } \\
\end{array}$ & $\begin{array}{c}\text { \% Decrease over } \\
\text { control }\end{array}$ \\
\hline 1 & 1000 & 1.90 & 5 & 5.6 & 5 \\
\hline 2 & 5000 & 1.80 & 10 & 5.3 & 7 \\
\hline 3 & 10000 & 1.80 & 10 & 4.7 & 17.54 \\
\hline \multirow[t]{2}{*}{4} & 50000 & 1.70 & 15 & 4.5 & 21.05 \\
\hline & Control & 2.00 & - & 5.7 & \\
\hline $\begin{array}{l}\text { Group } \\
\quad \text { B }\end{array}$ & $\begin{array}{c}\text { Inoculum } \\
\text { level }\end{array}$ & $\begin{array}{c}\text { Microsperma susceptible } \\
\text { ( ILL 5580) } \\
100 \text { Grain weight }\end{array}$ & $\begin{array}{c}\% \text { Decrease over } \\
\text { control }\end{array}$ & $\begin{array}{c}\text { Macrosperma susceptible } \\
\text { (ILL6002) } \\
100 \text { Grain weight }\end{array}$ & $\begin{array}{c}\text { \% Decrease over } \\
\text { control }\end{array}$ \\
\hline 1 & 1000 & 1.90 & 5 & 5.80 & 3.33 \\
\hline 2 & 5000 & 1.80 & 10 & 5.60 & 6.66 \\
\hline 3 & 10000 & 1.60 & 20 & 4.70 & 21.66 \\
\hline \multirow[t]{2}{*}{4} & 50000 & 1.40 & 30 & 3.60 & 40 \\
\hline & Control & 2.00 & - & 6.00 & - \\
\hline
\end{tabular}

The data regarding effect of different inoculum levels of A.lentis on 100 grain weight along with $\%$ decrease over control indicated that as the spore concentration increases from 1000 to 50,000 spores $/ \mathrm{ml}, 100$ grain weight decreases, this decrease being sharp in susceptible lines ILL 2580 and ILL 6002. In Microsperma Resistant (ILL 358) 100 grain wt at $1000,5000,10,000$ and 50,000 spores $/ \mathrm{ml}$ is $1.9,1.8$, 1.8 and 1.7 and their \% decrease over control is $5,10,10$ and $15 \%$ respectively. It showed that with increasing inoculum levels grain weight decreases as compared with one another as well as with the control (2.00 gram 100 grain wt). In MarcrosperTr-i3 100 grain wt of resistant (ILL 4605) variety at $1000,5000,10,000$ and 50,000 spores $/ \mathrm{ml}$ is 5.6, 5.3, 47 and 4.5 and \% decrease over control is $5,7,17.54$ and 21.05 respectively which indicates negative correlation between spore concentration and 100 grain wt. The un-inoculated plants had 100-grain wt. 5.7, which is quite higher than the 100-grain weight of, sprayed lentil plants. In Microsperma Susceptible (ILL 2580) 100 grain wt at spore concentration 1000, 5000, 10000 and 50,000 is $1.9,1.8,1.6,1.4$ with $\%$ decrease over control as $5,10,20,30 \%$ respectively. It indicates that with every one step increase in spore concentration, 100-grain weight decreases gradually as compared with the former as well as with control plants that had 2.00 gram 100 grain wt. This decrease is somewhat clear at spore level 10,000 and 50,000 where decrease over control reaches upto $20 \%$ and $30 \%$ respectively thus causing much yield reduction. In Macrosperma Susceptible (ILL 6002) there is clear reduction in 100 grain wt as compared with control that had 6.00 gram 100 grain wt. The inoculated plants 100 grain wt with \% decrease over control was 5.8 at 1000 spores $/ \mathrm{ml}$ with $3-33 \%$ decrease over control, 5.6 at 5000 spores $/ \mathrm{ml}$ with $6.66 \%$ decrease over control, 4.7 at 10000 spores $/ \mathrm{ml}$ with $21.66 \%$ decrease and 3.6 at 50,000 spores $/ \mathrm{ml}$ with almost $40 \%$ decrease over control. Thus the ILL6002 had maximum grain wt reduction at 50,000 spores/ml shows that 100 -grain wt decrease at a significant rate as spore concentration increased (Table 4).

\section{Discussion}

The studies were conducted to determine the effect of four different inoculum levels on the development of Ascochyta blight and growth of lentil plant. It involved the spraying of pre-prepared spore suspension on the lentil plants belonging to four different groups i.e. Microsperma Resistant (ILL358), Macrosperma Resistant (ILL4605), Microsperma Susceptible (ILL2580) and Macrosperma Susceptible (ILL6002). The response of these four- lentil lines to different inoculum levels, in terms of some growth and yield parameters were studied. It was noticed that plant height was minimum in case of all the four lentil lines at maximum spore load subjected i.e. 50,000 spores $/ \mathrm{ml}$. There was statistically significant decrease in plant height by increasing the inoculum level in all the lentil lines except lentil line ILL4605 (Macrosperma resistant). In ILL4605, the final plant height was statistically similar at the three lower inoculum levels and only at the maximum inoculum level it was statistically lower than at the other three inoculum levels. This trend may be attributed to the production of more antifungal compounds (phenols and phytoalexins). But on the other hand, if other parameters of the same lentil line (ILL4605) are taken into consideration the situation is similar as with other lentil lines. As far as the effect of increasing inoculum levels on plant height in terms of time period is concerned, perfect regression lines were observed in all the lentil lines (r-values highly significant) indicating the continued effect of fungal inoculum on these plants for about 10 weeks. It means that even the resistant lentil lines could not detoxify the toxins 
produced by the fungal spores.

In case of resistant lentil lines the number of leaflets decreased with the increase in spore level but statistically same numbers of leaflets per plant were recorded at 1000 , 5000 and 10000 spores $/ \mathrm{ml}$. Only at 50000 spores/ $\mathrm{ml}$ the statistically lower numbers of leaflets were recorded than other three inoculum levels. On the other hand, in case of susceptible group the number of leaflets/plant decreased gradually with the increase in inoculum level. This decrease was statistically significant. This indicates that in resistant group the plants were able to counteract the toxic effects of fungus at lower inoculum level but higher inoculum level $(50000$ spores $/ \mathrm{ml})$ was able to disrupt the defense of resistant plants and caused significantly higher shedding of leaflets compared with control and other inoculum levels.

Pod abortion is a common phenomenon in lentil plants. Among several other factors responsible for pod abortion pathogen pressure may also be responsible for this. The response of both resistant as well as susceptible plants for pod abortion at 1000 and 5000 spores $/ \mathrm{ml}$ was statistically similar in the respective groups. In resistant groups at the two higher inoculum levels (10000 and $50000 \mathrm{spores} / \mathrm{ml}$ ) the number of pods/plant was statistically same but on the other hand much lower number of pods/plant were recorded in susceptible group at the same inoculum levels. It means higher concentration of spores play a major role in pod abortion.

Grain formation is severely affected by lentil blight. As the spore concentration increases, number of grains/pod decrease. This decrease is quite conspicuous in the susceptible group. In the resistant group number of grains/pod are statistically similar at spore concentrations 1000 and 5000 spores $/ \mathrm{ml}$ but at higher spore load i.e. 10000 and 50000 spores $/ \mathrm{ml}$ number of grains are statistically much lower than the number of grains produced at 1000 and 5000 spores $/ \mathrm{ml}$ concentration. Thus higher concentration of spores disturbs even resistant group. Nevertheless resistant group is capable of detoxifying the fungal toxins thereby producing satisfactory number of grains/pod even at higher concentrations as compared with control. On the other hand the susceptible group produces number of grains that are statistically lower than the previous with every increasing spore concentration level, thus showing no capability to counteract the spore load.

Grain weight is quite important in estimating the ultimate yield reduction caused by the disease because the seeds from heavily infected plants are discolored, shriveled, smaller in size, light in weight [1, 3 \& 6]. In the resistant group 100-grain weight is not much affected at lower spore levels i.e. 1000 and 5000 spores $/ \mathrm{ml}$ but at higher concentration i.e. 10000 and 50000 spores $/ \mathrm{ml} 100$-grain weight decreases up to $21 \%$ as compared with control. It indicates that abundant spore load affects even resistant plants. But this is quite less than the effect observed on the susceptible group where 100-grain weight reduction is up to $40 \%$ as compared with control [2]. Hence it shows the advantage of resistant group over susceptible that lacks certain factors to detoxify the increasing spore load effects. As the resistant plants have sure capacity to counteract the fungal toxins by different mechanisms, they are much less affected by increasing spore concentrations as compared with susceptible group which is severely affected. In resistant group lesion size is much smaller with less frequency even at higher spore concentration as compared with susceptible group where lesion size reaches 4-6 mm with 5-8 frequency/pod. The seed size is significantly correlated to the level of seed-borne infection [6]. In the susceptible group seeds are smaller in size, shrivelled and lighter than the healthy seeds. Percentage recovery of Ascochyta lentis from susceptible group reaches up to 53\% at higher concentration i.e. 50000 spores $/ \mathrm{ml}$ which is much more than the percentage recovery of Ascochyta lentis from the resistant plant seeds at the same concentration i.e. $26 \%$.

\section{REFERENCES}

[1] G.M. Cromey, R.I. Mulholl, A.C. Russel and W.A. Jermyn. Ascochyta fabae f.sp. lentis on lentil in New Zealand. N.Z.J. Euprean Journal of Plant Pathology. 15:235-238, 1987.

[2] B.D. Gossen, and R.A.A. Morrall. Transmission of Ascochyta lentis from infected lentil seed and plant residue Canadian Journal of Plant Pathology. 8(1):28-32, 1986.

[3] C.J. Guerrero. Incidence and transmission of Ascochyta lentis Bond. And Vassil. On lentil seed. Agriculturea Tecnica. 47(2):101-107, 1987.

[4] W.J. Kaiser, and R.M. Hannan. incidence of seedbornce ascochyta lentis in lentil germplasm. Phytopathology. 76(3):355-360, 1986.

[5] B.A. Khan, I.U. Haq, F.U. Rehman and Aslam. Ascochyta blight of lentil -a new disease in Pakistan. Pakistan Journal of Botany. 15(2):121, 1983.

[6] A. Sattar. Acomparative study of fungi associated with blight diseases of certain cultivated leguminous plants. Trans. British Mycological Society. 18:278-301, 1934.

[7] J. Galloway, W.J. MacLeod. Epidemiology of ascochyta and botrytis diseases, in Crop Updates: Pulse Research and Industry Development in Western Australia, eds Regan K., White P., editors. (Perth: Agriculture Western Australia, Government of Western Australia. 91-95: 2002.

[8] W.J. Kaiser. Inter - and intranational spread of ascochyta pathogens of chickpea, faba bean and lentil. Canadian Journal of Plant Pathology. 19: 215-224. 10.1080/07060669709500556, 1997.

[9] W. Hawthorne, M. Materne, J. Davidson, K. Lindbeck, L. McMurray, J. Brand. Lentil Disease Management PA2012\#5. Melbourne, VIC: Pulse Australia, 2012. 
[10] W.J. Kaiser, B.C. Hellier. Didymella sp. the teleomorph of Ascochyta f. sp. lentis on lentil straw, APS Pacific Division Meeting Abstracts. Phytopathology. 83: 692, 1993.

[11] R.A.A. Morrall, J.W. Sheppard. Ascochyta blight of lentils in western Canada: 1978 to 1980. Canadian Plant Disease Survey. 61: 1-12, 1981.

[12] S.H. Martin, E.T. Steenkamp, M.J. Wingfield, B.D. Wingfield. Mate-recognition and species boundaries in ascomycetes. Fungal Divers. 58, 1-12. 10.1007/s13225-012-0217-2, 2013.

[13] B. Skiba, E.C.K. Pang. Mating trials and genetic study of virulence in Ascochyta lentis to the lentil cultivar 'Northfield'. Australia journal of Agricultural Research. 54: 453-460. 10.1071/AR02165, 2003.

[14] A.J. Ricker and R.S. Ricker. Introduction to research on plant diseases Johns Co. Mc., New York. 117, 1936. 